\title{
Transfer RNA Methyltransferase and Glycine N-Methyltransferase Activity during Rana pipiens Development
}

\author{
JUDITH E. HEADY \\ Department of Natural Sciences, University of Michigan, Dearborn, Michigan 48128
}

Received April 11, 1978; accepted in revised form September 7, 1978

\begin{abstract}
Changes in the activity of the tRNA methyltransferases have been found in all differentiating systems studied. Activity was examined in extracts of Rana pipiens embryos and in larval and adult liver by in vitro assay using $S$-adenosyl-L- $\left[\right.$ methyl- $\left.{ }^{14} \mathrm{C}\right]$ methionine as the methyl donor. Specific activities of tRNA methyltransferases decreased, beginning with the time of feeding, when using high concentrations of the crude liver enzyme. A new methyltransferase activity, glycine $N$. methyltransferase, appeared at the time of feeding. Apparently, the glycine methyltransferase is active before the onset of any of the characteristic metamorphic changes of other liver enzymes. Using partially purified enzyme from adult liver, the $K_{m}$ of glycine methyltransferase for $S$ adenosylmethionine is $0.3 \mathrm{mM}$ and the $K_{i}$ for $S$-adenosylhomocysteine, a competitive inhibitor, is $0.08 \mathrm{mM}$.
\end{abstract}

\section{INTRODUCTION}

Many biological systems undergoing changes in regulation have been studied with respect to changes in activity of tRNA methyltransferases (summarized in Kerr, 1974; Law et al., 1976, 1977). The variable additions of methyl groups to the bases of tRNA at the macromolecular level, as well as other modifications of tRNA, will change the structural conformation of the molecules and may change the fit to ribosomes (Fittler and Hall, 1966; Thiebe and Zachau, 1968; Gefter and Russell, 1969), the interaction with DNA (Singer et al., 1972), codon recognition (Capra and Peterkofsky, 1968; Smith, 1975) or aminoacylation (Shugart et al., 1968). Regions of tRNA which could be altered structurally and have functional significance have been described by Quigley and Rich (1976). The possibilities of fine control by changing tRNAs after transcription exists because the methyltransferases are specific for each organism species, tissue type, base, and base sequence. Differences in levels of methylation within various specific tissues over the developmental period of the organism may be in part due to competing enzyme systems which generally appear during early postembryonic stages and increase to adult stage (Kerr, 1972, 1974). The actual systems vary from tissue to tissue, but they have in common (1) competition for substrate, $S$. adenosylmethionine, and (2) differential sensitivity to inhibition by the end-product $S$-adenosylhomocysteine.

Metamorphosis in amphibians is a unique secondary time of developmental change which is dependent on the hormone thyroxine (Kollros, 1961). In a preliminary study, Pillinger et al. (1971) found changes in tRNA methyltransferase activity in liver and tail tissue in thyroxine-stimulated Rana catesbeiana larvae. Since many liver enzymes are newly synthesized or change from larval to adult forms at the time of metamorphosis, the appearance of a new methyltransferase activity might be dependent on the hormone thyroxine.

Data presented will show that tRNA methyltransferase activity from liver does not change dramatically at metamorphosis, but that a new methyltransferase activity, glycine methyltransferase, appears at the 
time of feeding in $R$. pipiens. The appearance or activation of glycine methyltransferase does not depend on the hormone thyroxine, because livers from hypophysectomized animals have glycine methyltransferase activity.

\section{MATERIALS AND METHODS}

Chemicals. S-Adenosyl-L-[methyl $\left.\cdot{ }^{14} \mathrm{C}\right]-$ methionine $(51.8 \mathrm{mCi} / \mathrm{mmole})$ was purchased from International Chemical and Nuclear Corporation. Escherichia coli tRNA was bought from General Biochemicals. Hydroxylapatite was the product of Bio-Rad.

Animals. Sexually mature $R$. pipiens were obtained from C. Mumley Frog Farm, Alburg, Vermont. Some sexually mature females and some stages of embryos and larvae were purchased from The Amphibian Facility, University of Michigan, Ann Arbor. Females were induced to ovulate by intraperitoneal injection of from 2 to $5 R$. pipiens pituitaries 24 to $48 \mathrm{hr}$ before the time of fertilization. Males were sacrificed and the testes crushed to provide viable spermatozoa. Any defective embryos were discarded.

All premetamorphic animals were raised at $21-25^{\circ} \mathrm{C}$ in aerated tap water. Adults were used immediately on arrival or kept in tap water at $4^{\circ} \mathrm{C}$ until they were used.

Some frozen adult $R$. pipiens livers were purchased from Pel-Freez Biologicals, Inc., Rogers, Arkansas.

Hypophysectomy. Embryos of stages 17-18 were hypophysectomized using glass needles according to established methods (Rugh, 1962). These animals were raised separately from normal animals and used only after all of the siblings had gone through metamorphosis (from 8 to 12 months after fertilization).

Preparation of enzyme extracts. Animals were sacrificed by decapitation after slowing in water at $4^{\circ} \mathrm{C}$ or in anesthetic, ethyl$m$-aminobenzoate methanesulfonic acid $(0.01 \%)$. Tissues were used immediately for tests for tRNA methyltransferase activity, but some were frozen at $-20^{\circ} \mathrm{C}$ for tests for glycine methyltransferase activity.

Liver or embryos were minced and homogenized in 4 vol of $0.01 M$ Tris- $\mathrm{HCl}, \mathrm{pH}$ $7.4,0.01 \mathrm{M} \mathrm{NaCl}$, and $0.0015 \mathrm{M} \mathrm{MgCl}_{2}$ using a motor-driven Teflon-glass tissue grinder. This homogenate was centrifuged at $15,000 \mathrm{~g}$ for $10 \mathrm{~min}$ and the resulting supernatant was centrifuged at $105,000 \mathrm{~g}$ for 60 min. The high-speed supernatant was used directly to measure the tRNA methyltransferase activity. The tRNA methyltransferase enzymes were removed by precipitation with $1.0 \mathrm{M}$ acetic acid to $\mathrm{pH} 5.0$ and subsequent centrifugation at $10,000 \mathrm{~g}$ for 10 min; glycine methyltransferase was left in the supernatant. The supernatant was reneutralized with $1.0 \mathrm{M} \mathrm{Na} 2 \mathrm{CO}_{3}$. The preparation was directly desalted on a Sephadex G-25 column to remove glycine or was concentrated with the addition of $4.0 \mathrm{~g}$ $\left(\mathrm{NH}_{4}\right)_{2} \mathrm{SO}_{4}$ per $10 \mathrm{ml}$ of solution before desalting. The high-molecular-weight column eluate was used for glycine methyltransferase activity assays.

Partial purification of glycine methyltransferase. Twenty to forty grams of adult liver was prepared as above. The concentrated pH 5.0 supernatant was dissolved in hydroxylapatite column buffer, $0.01 M$ sodium phosphate, $\mathrm{pH}$ 7.1, $0.01 M$ Tris- $\mathrm{HCl}$, and $0.001 M$ dithiothreitol and desalted on a Sephadex G-25 column. The high-molecular-weight eluate was dialyzed at $4^{\circ} \mathrm{C}$ for $24 \mathrm{hr}$ against three changes of column buffer. At the same time a $2.5 \times 9.0-\mathrm{cm}$ hydroxylapatite column was poured and washed at $4^{\circ} \mathrm{C}$ with column buffer. A 300$\mathrm{ml}$ linear gradient of 0.01 to $0.1 \mathrm{M}$ sodium phosphate in column buffer was used to elute the proteins. Column fractions were analyzed for glycine methyltransferase activity and the peak fractions were pooled and used for kinetic experiments.

Assay of tRNA methyltransferases. The standard assay mixture contained $10 \mu$ mole of Tris- $\mathrm{HCl}, \mathrm{pH} 8.2,1 \mu$ mole of $\mathrm{MgCl}_{2}, 0.2$ 
$\mu$ mole of dithiothreitol, $10 \mu \mathrm{g}$ of $E$. coli B tRNA, 2 nmole $(0.1 \mu \mathrm{Ci})$ of $S$-adenosyl$\mathrm{L}-\left[\right.$ methyl $\left.-{ }^{14} \mathrm{C}\right]$ methionine, and varying amounts of enzyme extract in a total volume of $0.2 \mathrm{ml}$. Control assays were done without tRNA. After incubation at $27^{\circ} \mathrm{C}$ for 30 min the reaction was terminated by the addition of $0.2 \mathrm{ml}$ of $10 \%$ TCA. Precipitates were collected on Whatman GF/C filters which had been pretreated with $0.1 M$ EDTA; the filters were next washed with $5 \%$ TCA. The filters were dried under an infrared lamp and were counted in a Beckman 8100 liquid scintillation counter with a counting efficiency of $90-95 \%$.

Assay of glycine methyltransferase. The standard assay mixture contained $10 \mu$ mole of Tris- $\mathrm{HCl}, \mathrm{pH} 8.6,0.2 \mu$ mole of dithiothreitol, $1 \mu$ mole of glycine, 2 nmole $(0.1$ $\mu \mathrm{Ci})$ of $S$-adenosyl-L-[methyl $\left.-{ }^{14} \mathrm{C}\right]$ methionine, and varying amounts of enzyme extract in a total volume of $0.2 \mathrm{ml}$. Control assays were done without glycine. After incubation at $27^{\circ} \mathrm{C}$ for $30 \mathrm{~min}$ for enzyme activity assays, $5 \mu$ mole of adenosine was added as a carrier and the assays were precipitated at $4^{\circ} \mathrm{C}$ with $50 \mu \mathrm{I}$ of $20 \%$ phosphotungstic acid. Distilled water at $4^{\circ} \mathrm{C}$ was added to a final volume of $1 \mathrm{ml}$. The unreacted $S$-adenosylmethionine and the precipitated protein were removed by centrifugation at $30,000 \mathrm{~g}$ for $20 \mathrm{~min}$. An aliquot of $100 \mu \mathrm{l}$ of the supernatant containing the labeled product, sarcosine, was added to 7 $\mathrm{ml}$ of Tritosol (Fricke, 1975) and counted in a Beckman 8100 scintillation counter with a counting efficiency of $70-74 \%$. Some of the conditions were varied for kinetic assays as detailed in Fig. 2.

In order to check for the authenticity of the methylated product, sarcosine, two-dimensional thin-layer chromatography of the supernatant described above and of glycine and sarcosine standards was done (Kerr, 1972).

Assay of protein. Protein was determined by the method of Lowry et al. (1951) with bovine serum albumin as the standard.

\section{RESULTS}

\section{tRNA Methyltransferase Activity}

tRNA methyltransferase activity measured by assays of incorporation of ${ }^{14} \mathrm{CH}_{3}$ groups of $S$-adenosylmethionine into a saturating level of substrate, $E$. coli B tRNA, is high in prefeeding $R$. pipiens embryos and in hypophysectomized larval liver. The activity is lower in normal-feeding-stage larvae and in adult liver (Fig. 1). Liver extracts from normal-feeding-stage larvae of Stage I (Taylor and Kollros, 1946) through metamorphosis and from adults have decreasing activity with increasingly high levels of protein in assays.

\section{Glycine Methyltransferase Activity}

Activation of the enzyme system, glycine methyltransferase, occurred at the time of feeding (Stage I) in $R$. pipiens larvae (Table 1). Glycine methyltransferase activity was measured by the assay of incorporation of ${ }^{14} \mathrm{CH}_{3}$ groups of $S$-adenosylmethionine into a saturating level of glycine. Generally the appearance and the level of glycine methyltransferase activity vary inversely with the level of tRNA methyltransferase activity.

Two-dimensional thin-layer chromatography of the reaction verified that the radioactivity above the background value was present coincident with the sarcosine standard.

\section{Characterization of Partially Purified Glycine Methyltransferase}

The $R$. pipiens glycine methyltransferase requires $\mathrm{Mg}^{2+}$, a sulfhydryl reagent, and is maximally active under the assay conditions used between $\mathrm{pH} 8.0$ and 8.8. The crude or relatively pure enzyme is not stable in solution when stored at 4 or at $-20^{\circ} \mathrm{C}$. Antibody to rabbit liver glycine methyltransferase (Heady and Kerr, 1975) did not cross-react with the enzyme from $R$. $p i$ piens liver. Glycine methyltransferase displays Michaelis-Menten kinetics. When the concentration of $S$-adenosylmethionine 


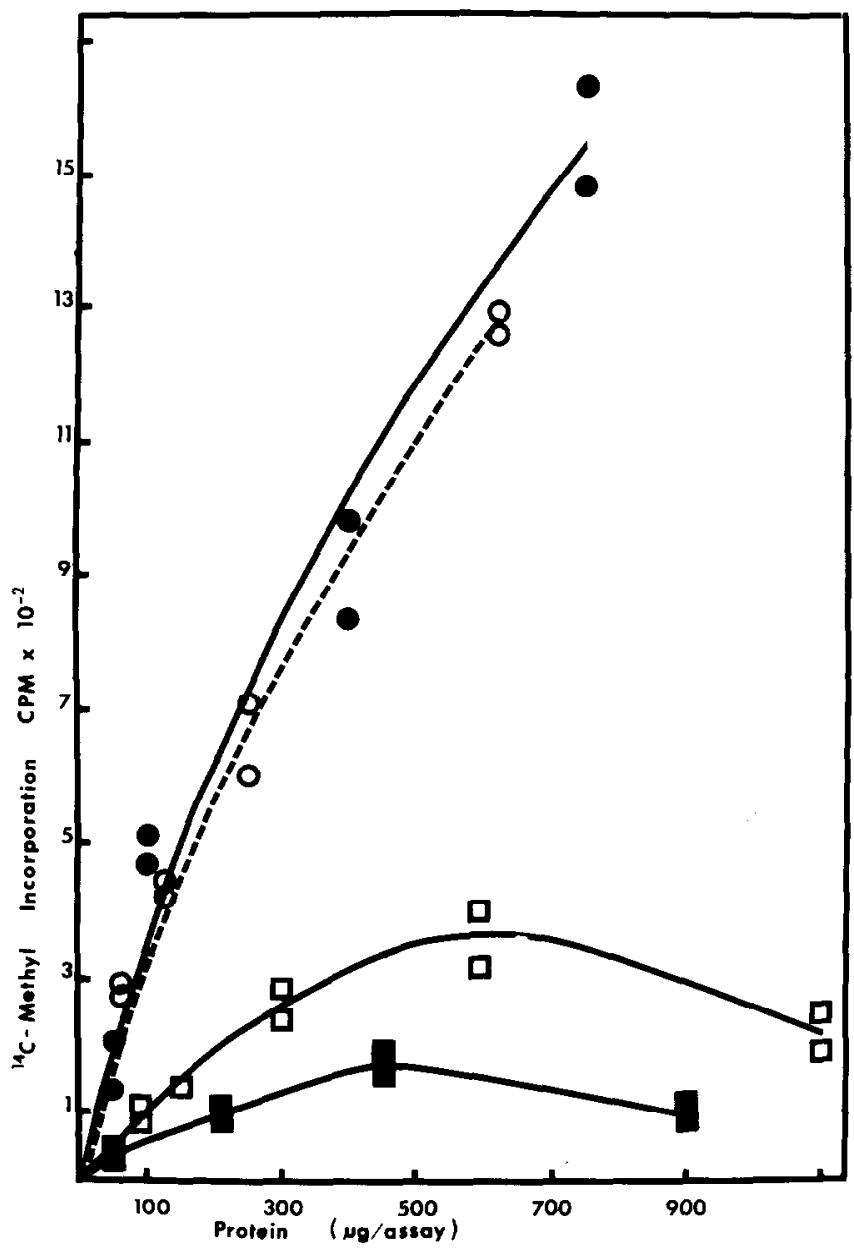

FIG. 1. tRNA methyltransferase activity during development in Rana pipiens. The incorporation of ${ }^{14} \mathrm{CH}_{3}$ groups from $S$-adenosylmethionine into Escherichia coli B tRNA was measured as described under Materials and Methods. Control assay values have been subtracted from all experimental points. The points are representative assays for embryos $\left(O_{-}\right)$, larval stage IX-X liver $(\square-\square)$, hypophysectomized larval liver $(\mathrm{O}--\mathrm{O})$, and adult liver $(\square-\square)$.

is varied and glycine is saturating, the Michaelis constant $\left(K_{m}\right)$ for $S$-adenosylmethionine is $0.3 \mathrm{mM}$. The enzyme is competitively inhibited by the product $S$-adenosylhomocysteine; the $K_{i}$ value is $0.08 \mathrm{mM}$ (Fig. 2).

When the concentration of glycine is varied and $S$-adenosylmethionine is saturating, the Michaelis constant $\left(K_{m}\right)$ for glycine is $0.41 \mathrm{mM}$.

\section{DISCUSSION}

The activity of tRNA methyltransferases from embryonic $R$. pipiens is high com- pared with that of normal larval and adult liver. This pattern follows other systems which have been tested (Kerr, 1974). The glycine methyltransferase enzyme system of $R$. pipiens is comparable to that of mammals with respect to time of its appearance, at larval-fetal stages (Heady and Kerr, 1975), and the conditions of enzyme activity and kinetics (Heady and Kerr, 1973). The Michaelis and inhibitor constants of rabbit liver glycine methyltransferase for $S$-adenosylmethionine are 0.1 and $0.035 \mathrm{mM}$ (with $S$-adenosylhomocysteine), respectively (Heady and Kerr, 1973). However, the 
TABLE 1

Glycine Methyltransferase Activity and tRNA Methyltransferase Activity IN $R$. pipiens $\operatorname{LIVER}^{a}$

\begin{tabular}{|c|c|c|}
\hline Tissue & $\begin{array}{c}\text { Glycine melh- } \\
\text { yltransferase } \\
\text { (nmol } / \mathrm{mg} / 30 \\
\mathrm{~min})\end{array}$ & $\begin{array}{l}\text { IRNA Methy] } \\
\text { transferase } \\
(\mathrm{nmol} / \mathrm{mg} / 30 \\
\mathrm{min})\end{array}$ \\
\hline Embryos $^{b}$ & Not detected & 0.029 \\
\hline \multicolumn{3}{|l|}{ Larva $^{c}$} \\
\hline I-II & 20.4 & 0.031 \\
\hline VI-VIII & 19.2 & 0.007 \\
\hline IX-XIII & 25.4 & 0.013 \\
\hline Adult & 45.5 & 0.008 \\
\hline \multicolumn{3}{|l|}{ Metamorphic climax } \\
\hline $\mathrm{XX}-\mathrm{XXIV}{ }^{c}$ & $10.2^{d}$ & 0.005 \\
\hline Hypophysectomized ${ }^{e}$ & 8.6 & 0.021 \\
\hline
\end{tabular}

${ }^{a}$ Values are averages of from three to six separate determinations. Control assay values have been subtracted from all experimental points.

${ }^{b}$ Total embryos of Stages 21-25.

c Taylor-Kollros stages.

${ }^{d}$ Repeated tests were low. This could indicate complex enzyme interactions during metamorphic climax.

${ }^{e}$ From 8 to 12 months of age, with no more than Stage VII leg. mammalian enzyme is stable in solution at $4^{\circ} \mathrm{C}$ for several weeks, but the frog enzyme is not stable in solution. Antibody to rabbit glycine methyltransferase does not crossreact with the frog liver enzyme.

The anuran was chosen for this developmental study, because metamorphosis is a time of new synthesis in the liver and this synthesis is controlled by the hormone thyroxine. Although many liver enzymes change during metamorphosis (Cohen, 1970), glycine methyltransferase activity does not appear to be controlled by thyroxine. Glycine methyltransferase activity is measurable before the premetamorphic stages of development (during Stages I-VIII) when thyroxine levels are very low (Kollros, 1961; Etkin, 1964) and in hypophysectomized animals where thyroxine is absent.

A change in relative amounts of two major leucyl tRNAs has been reported in $R$.

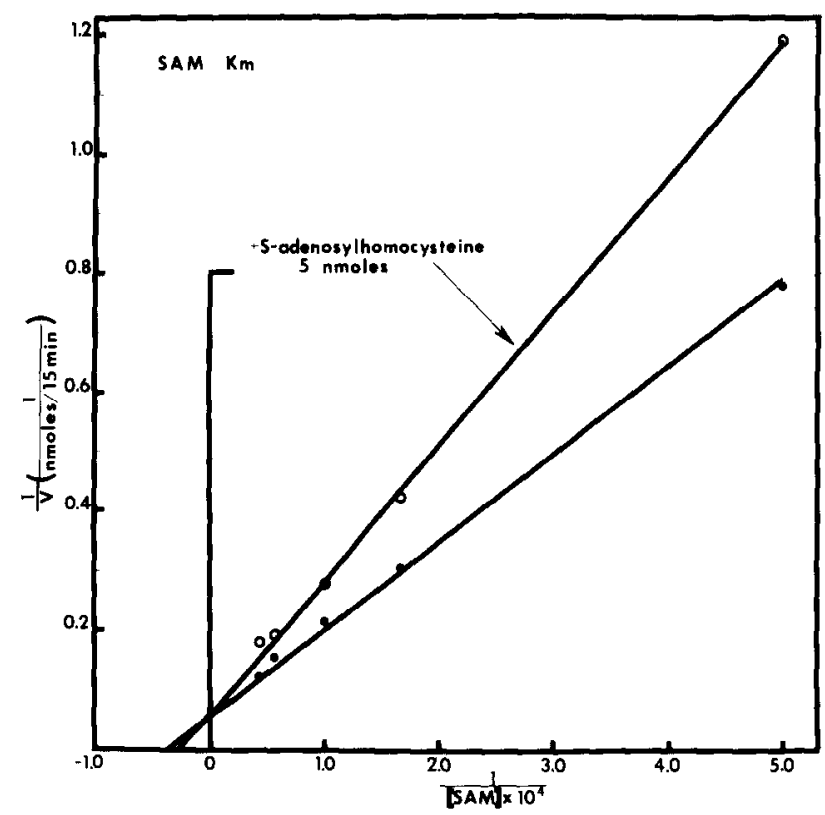

FIG. 2. Determination of the kinetic constant of $S$-adenosylmethionine. Values represent the averages of quadruplicate assays. Assays had $13 \mu \mathrm{g}$ of glycine methyltransferase and were incubated for $15 \mathrm{~min}$ at $27^{\circ} \mathrm{C}$. Assays contained $2 \mu$ mole of glycine and varying amounts of $S$-adenosylmethionine in the absence of $S$ adenosylhomocysteine (-) and in the presence of 5 nmole of $S$-adenosylhomocysteine $(O-O)$. Control assay values have been subtracted from all experimental points. The lines were drawn to fit the points with the help of a computer program for a least-squares plot. 
catesbeiana liver during spontaneous and triiodothyronine-induced metamorphosis (Tongue et al., 1969), a time of new protein synthesis. The new conditions including altered relative amounts of different amino acids require correspondingly altered relative amounts of some species of tRNAs (Smith, 1975; Garel, 1976). A species of tRNA could be limiting until a certain point in development when this species might be synthesized preferentially or in some cases might be differentially modified postsynthetically (Smith, 1975). The differential modification might include methylation of tRNAs by tRNA methyltransferases competitively controlled by enzyme systems such as glycine methyltransferase.

Pillinger et al. (1971) reported that during thyroxine-induced metamorphosis the activity of tRNA methyltransferases changed in specific patterns in tail tissue and in liver and that possibly a hormonecontrolled inhibitor system was involved. The decrease in activity of tRNA methyltransferase was transitory. It is not known if a competing enzyme was involved. However, there are differences in activities of tRNA methyltransferases between hypophysectomized and normal larvae when high protein concentrations are used (Fig. 1 and Table 1). Although the crude enzyme preparation $(105,000 \mathrm{~g}$ supernatant) contained both enzymes, each might be compartmentalized within living cells.

There is some preliminary evidence that glycine methyltransferase might act as a competitive enzyme system in larval and adult frog liver. First, as protein concentration increases in tRNA methyltransferase assays, using crude $105,000 \mathrm{~g}$ supernatant, activity is depressed (Fig. 1). Second, there is a general correlation of the presence of glycine methyltransferase and this depression. Third, when the $\mathrm{pH} 5.0$ precipitated protein from all normal larval and adult stages is used as the tRNA methyltransferase enzyme source there is a linear increase in activity as shown for the crude superna- tant of the embryos (Fig. 1) (Heady, unpublished; Kerr, 1974). In this case the glycine methyltransferase activity remains in the pH 5.0 supernatant and is removed from the reaction.

Changes in the tRNA population of certain tissues due to hormone stimulation might also alter the protein synthesis quantitatively. In a tRNA-dependent in vitro protein-synthesizing system almost twice the ovalbumin is synthesized when the tRNA extracted from estrogen-stimulated chick oviducts or laying-hen oviducts is used compared with tRNA extracted from withdrawn chick oviducts (Sharma et al., 1975, 1976).

Glycine methyltransferase makes up $2.5 \%$ of the soluble liver protein in the rabbit (Heady and Kerr, 1975) and although the percentage of glycine methyltransferase in frog liver is not known, it is significant. This enzyme would seem to be an important part of vertebrate digestive glands [glycine methyltransferase is also present in mammalian pancreas (Kerr, 1972)]. The presence of the enzyme system in adult crustacean digestive glands, Callianassa gigas and Homarus americanus (Heady, unpublished), further lends support to the possible significance of this enzyme for control of the critical activity of tRNA methyltransferases during development and possibly for indirect control of other enzymes using $S$-adenosylmethionine or $S$-adenosylhomocysteine as substrate (Kerr and Heady, 1974).

I wish to thank my students David McFarlane, Nancy Cafmeyer, Sharon Helmer, Ann Brey, and Karl Agee for help with portions of this study. I wish to thank The Rackham School of Graduate Studies, the University of Michigan, Ann Arbor, for support for 1975-1976, and the Campus Grants Committee, the University of Michigan, Dearborn, for support for 1974-1977. Special thanks go to Dr. Christina Richards of the Amphibian Facility, the University of Michigan, Ann Arbor, for advice and help obtaining animals; to Dr. Roberta Kleinman, Department of Natural Sciences, University of Michigan, Dearborn, for preparation and execution of a computer program for the 
enzyme kinetic data; and to Drs. Myrtle Palmer and R. W. Trewyn for critical reading of the manuscript.

\section{REFERENCES}

Capra, J. D., and Peterkofsky, A. (1968). Effect of in vitro methylation on the chromatographic and coding properties of methyl-deficient leucine transfer RNA. I. Mol. Biol. 33, 591-607.

Cohen, P. P. (1970). Biochemical differentiation during amphibian metamorphosis. Science 168, 533-543.

EtKin, W. (1964). Metamorphosis. In "Physiology of the Amphibia" (J. A. Moore, ed.), pp. 427-468. Academic Press, New York.

FitTler, F., and Hal.L, R. H. (1966). Selective modification of yeast seryl tRNA and its effect on the acceptance and binding functions. Biochem. Bio phys. Res. Commun. 25, 441-446.

Fricke, U. (1975). Tritosol. A new scintillation cocktail based on Triton X-100. Anal. Biochem. 63, 555-558.

GAREL, J. P. (1976). Quantitative adaptation of isoacceptor tRNA's to mRNA codons of alanine, glycine and serine. Nature (London) 260, 805-896.

Gefter, M. L., and Russell, R. L. (1969). Role of modification in tyrusine transfer RNA: A modified base affecting ribosome binding. J. Mol. Biol. 39, 145-157.

HEADY, J. E., and KERR, S. J. (1973). Purification and characterization of glycine $N$-methyltransferase. $J$. Biol. Chem. 248, 69-72.

HEADY, J. E., and KERR, S. J. (1975). Alteration of glycine $N$-methyltransferase activity in fetal, adult and tumor tissues. Cancer Res. 35, 640-643.

KERR, S. J. (1972). Competing methyltransferase systems. J. Biol. Chem. 247, 4248-4252.

KERR, S. J. (1974). Control of tRNA methyltransferase activity by competing enzyme systems. In "Control Processes in Neoplasia" (M. A. Mehlman and R. W. Hanson, eds.), pp. 83-102. Academic Press, New York.

KERR, S. J. (1975). Interaction of mammalian tRNA methyltransferases with heterologous and homologous tRNA, Advan. Enzyme Regul. 13, 379-390.

KeRR, S. J., and HEADY, J. E. (1974). Modulation of tRNA methyltransferase activity by competing enzyme systems. Advan. Enzyme Regul. 12, 103-117.

KollRos, J. J. (1961). Mechanisms of amphibian metamorphosis: Hormones. Amer. Zool. 1, 107-114.

Law, R. E., Ferro, A. J., Cummings, M. R., and
ShAPIRo, S. K. (1976). tRNA methyltransferases during embryogenesis in Musca domestica. Develop. Biol. 54, 304-307.

LaW, R. E., Ferro, A. J., Cummings, M. R., and Shapiro, S. K. (1977). S-Adenosylmethionine: Homocysteine methyltransferase during embryogenesis in Musca domestica. Develop. Biol. 59, 263-265.

Lowry, O. H., Rosebrough, N. J., Farr, A. L., and RANDALL, R. J. (1951). Protein measurement with the Folin phenol reagent. J. Biol. Chem. 193, 265-275.

Pillinger, D. J., Borek, E., and PaIK, W. K. (1971). The tRNA methylases during thyroxine-induced differentiation in bull frog tadpoles. $J$. Endocrinol. 49, 547-548.

QUigley, G. J., and RICH, A. (1976). Structural domains of transfer RNA molecules. Science 194, 796-806.

Rugh, R. (1962). "Experimental Embryology," pp. 322-324. Burgess, Minneapolis.

Sharma, O. K., BeEzLey, D. N., and Borek, E. (1976). Modulation of the synthesis in vitro of a hormoneinduced protein by transfer RNA. Nature (London) 262, 62-63.

Sharma, O. K., Roberts, W. K., Beezley, D. N., and BoREK, E. (1975). A transfer RNA-dependent protein synthesizing system from Ehrlich ascites extracts. Biochim. Biophys. Acta 390, 327-331.

Shugart, L., Novelli, G. D., and Stulberg, M. P. (1968). Isolation and properties of undermethylated phenylalanine transfer RNA from a relaxed mutant of Escherichia coli. Biochim. Biophys. Acta 157, $83-90$.

Singer, C. E., Smith, G. R., Cortese, R., and Ames, B. N. (1972). Mutant tKNA ${ }^{\text {His }}$ ineffective in repression and lacking two pseudouridine modifications. Nature New Biol. 238, 72-74.

SMITH, D. W. E. (1975). Reticulocyte transfer RNA and hemoglobin synthesis. Science 190, 529-535.

TAYLoR, A. C., and Kollros, J. J. (1946). Stages in the normal development of Rana pipiens larvae. Anat. Rec. 94, 7-23.

Thiebe, R., and Zachau, H. (1968). A specific modification next to the anticodon of phenylalanine transfer ribonucleic acid. Eur. J. Biochem. 5, 546-555.

Tongue, T., Eaton, J. E., and Frieden, E. (1969). Changes in leucyl-tRNA during spontaneous and induced metamorphosis of bullfrog tadpoles. Biochem. Biophys. Res. Commun. 37, 81-88. 